\title{
The Influence of Abiotic Factors on an Invasive Pest of Pulse Crops, Sitona lineatus (L.) (Coleoptera: Curculionidae), in North America
}

\author{
O. Olfert, ${ }^{1}$ R. M. Weiss, ${ }^{1}$ H. A. Cárcamo, ${ }^{2}$ and S. Meers ${ }^{3}$ \\ ${ }^{1}$ Agriculture and Agri-Food Canada, Saskatoon Research Centre, 107 Science Place, Saskatoon, SK, Canada S7N 0X2 \\ ${ }^{2}$ Agriculture and Agri-Food Canada, Lethbridge Research Centre, 5403 1st Avenue South, Lethbridge, AB, Canada T1J 4B1 \\ ${ }^{3}$ Alberta Agriculture and Rural Development, Brooks Research Centre, 131 S.S. No.4 Brooks, AB, Canada T1R 1E6
}

Correspondence should be addressed to O. Olfert, owen.olfert@agr.gc.ca

Received 15 July 2011; Revised 23 September 2011; Accepted 27 September 2011

Academic Editor: Nikos T. Papadopoulos

Copyright (C) 2012 O. Olfert et al. This is an open access article distributed under the Creative Commons Attribution License, which permits unrestricted use, distribution, and reproduction in any medium, provided the original work is properly cited.

\begin{abstract}
Pea leaf weevil, Sitona lineatus (L.), native to Europe and North Africa, has been introduced into many other countries around the world, including the USA and Canada. Adults are oligophagous pests on leguminaceous plants. Sitona lineatus was first recorded in Canada in 1997, near Lethbridge, Alberta. Since then, it has spread north in Alberta and west into Saskatchewan in 2007. Bioclimatic simulation models were used to predict the distribution and extent of establishment of S. lineatus in Canada based on its current geographic range, phenology, relative abundance, and empirical data. The study identified areas in Canada that are at risk for future establishment of $S$. lineatus and developed a better understanding of climate effects. Climate change projections (General Circulation Models) were then imposed on the bioclimatic model of S. lineatus. Bioclimatic model output varied for each of the three General Circulation Models. In terms of suitability for pest establishment (Ecoclimatic Index), the NCAR273 CCSM climate data resulted in the most significant shift northward.
\end{abstract}

\section{Introduction}

Pea leaf weevil, Sitona lineatus (L.), native to Europe and North Africa, has been introduced into many other countries around the world, including North America. Adults are oligophagous pests on leguminaceous plants. Sitona lineatus was first recorded in Canada in 1997, near Lethbridge, Alberta. [1-3]. The adults are oligophagous pests on leguminaceous plants but prefer and maximize their reproductive potential on peas and faba beans [4]. The species has one generation per year [5]. Adults overwinter in a variety of locations, particularly sites containing perennial legumes and weeds. In spring, adults leave overwintering sites in search of pea fields. Eggs are laid in the soil, near developing pea plants. Larvae feed on root nodules and develop through five instars. Pupation occurs in the soil. In late summer adults leave pea fields in search of late season pulse crops before overwintering [6]. Adults feed on leaf margins of legume seedlings. Larval feeding on nodules can result in partial or complete inhibition of nitrogen fixation [7].
Sitona lineatus was first collected in Canada in 1997, near Lethbridge, Alberta [4]. Since then, it has spread northward in Alberta and east into Saskatchewan in 2007 [8, 9]. The introduction of $S$. lineatus into this region presents a risk to pea production in Northern Great Plains of Canada and USA $[10,11]$.

Abiotic factors, primarily climate, constrain population growth and survival that ultimately affect species distribution and abundance [12]. Bioclimatic simulation models have been used successfully to predict the distribution and extent of insect establishment in new environments [13-17]. Bioclimatic modelling software, such as CLIMEX [14], enables the development of models that describe the potential distribution and seasonal abundance of a species based on climate. Inferential models infer a species response to climate, based on its geographic range, phenology, seasonal abundance, and empirical data. CLIMEX models allow researchers to develop an overview of climatic factors that affect species distribution and abundance and permit identification of nonclimatic factors that limit species distribution [14]. Sensitivity 
analysis can be used to test hypotheses related to the effect of varying climate variables (i.e., warmer/cooler or wetter/dryer than normal conditions) on the species distribution and abundance [14].

The objectives of the study were to develop a bioclimatic model to predict potential range and relative abundance of $S$. lineatus, to identify areas in Canada that are at risk for future establishment of the pea leaf weevil, and to use the model to develop a better understanding of how a changing climate might potentially influence $S$. lineatus populations across North America.

\section{Methods}

The bioclimatic modeling process has been previously described $[15,18,19]$. CLIMEX models derive Ecoclimatic Index (EI) values that describe the climatic suitability, in terms of insect survival and reproduction, of specific locations. The respective Growth Indices and Stress Indices (with related parameters) are illustrated in Table 1. The EI value integrates annual growth (GI) with annual stress (heat, cold, dry, wet) to produce a single value (between 1 and 100) for each location. Ecoclimatic Index values near zero indicate that the location's climate is not suitable for long-term establishment of the species. An EI value greater than 20 indicates a "Very Favourable" climate.

Initial model parameter values were based on published data that resulted from laboratory and field studies [3, 6, 2024] and are defined in Table 1. Climatic requirements were inferred from known distributions of pea leaf weevil in Europe. The model for S. lineatus, using CLIMEX 3.0 [14], was developed by iteratively adjusting parameter values to produce mapped results that closely approximated observed distribution for S. lineatus in Europe [1-3]. Model parameterization was conducted for Britain, Denmark, France, Germany, Switzerland, Norway, and The Netherlands. The remaining European countries were treated as an independent dataset and used for model validation. Once the European distribution was defined, based on a visual comparison of model output with observed distribution, EI values were compared to reported data on relative abundance. Published results related to abundance were used to refine parameter values so that highest EI values occurred where $S$. lineatus was known to cause damage and lower values occurred when the species was less prevalent.

The model was validated by comparing output to reported distributions and seasonal phenology and tested for consistency with empirical data. Three methods were used to validate the model. The model was then applied to predict the population distribution of $S$. lineatus in eastern Europe (Bulgaria, Czech Republic, Hungary, Poland, Romania, Slovakia, Ukraine, and Yugoslavia), Asia, Washington, Oregon, and Idaho. Model output for these regions was compared to known distributions as reported by Schotzko and Quisenberry [25], Fauna Europaea Web Service [1], and Hoebeke and Wheeler Jr. [3]. Second, model output for phenology and life history was compared to published reports for Europe $[22,26]$. Third, model results which related to insect phenology were based on weather data and insect population data collected from southern Alberta [27].

The CLIMEX model required five meteorological inputs: temperature (maximum and minimum), precipitation, and relative humidity (09:00 and 15:00 hours). The Compare Locations function required monthly long-term average climatic variables. Climate data was used as an input for the Compare Locations function. The dataset represents a splined $0.5^{\circ}$ world grid dataset [28]. Models were run for Europe $\left(n=6416\right.$ grids) and Canada (south of $65^{\circ} \mathrm{N}$ latitude, $n=4472$ grids). The moisture index (MI) is based on a calculated soil moisture value. CLIMEX used a hydrological submodel to compute a weekly soil moisture balance. Soil moisture balance was based on soil moisture from the previous week, current week values for precipitation and evapotranspiration. CLIMEX used a degree-day model, based on the algorithm published by Baskerville and Emin [29], to compute the temperature index (TI) and the potential number of generations per year.

Climate change projections were obtained from the Intergovernmental Panel on Climate Change [30] as monthly means for three General Circulation Models (GCMs), based on current climate, 30-year average (1961-1990) dataset (A1B emission scenario) (CRU: Climate Research Unit, East Anglia, UK). The GCMs used were CSIRO Mark 3.0 (CSIRO, Australia), NCAR273 CCSM (National Centre for Atmospheric Research, USA), and MIROC-H (Centre for Climate Research, Japan). All three had the requisite climatic variables at a temporal resolution appropriate for CLIMEX and were pattern-scaled to develop individual change scenarios relative to the base climatology [31]. The GCMs cover a range of climate sensitivity, defined as the amount of global warming for a doubling of the atmospheric $\mathrm{CO}_{2}$ concentration compared with 1990 levels [32]. The respective sensitivities are CSIRO Mark $3.0\left(2.11^{\circ} \mathrm{C}\right)$, NCAR$\operatorname{CCSM}\left(2.47^{\circ} \mathrm{C}\right)$, and MIROC-H $\left(4.13^{\circ} \mathrm{C}\right)$.

In order to query the resulting database at a regional scale, a geographic rectangle, $4^{\circ}$ latitude by $7^{\circ}$ longitude, was used to delineate a regional template consisting of 112 grid cells. Specific regions, based on latitude and longitude coordinates, were defined and output (averaged across the region) was generated for detailed analysis. The datasets permitted comparison of variables, both spatially and temporally (weekly intervals). Analyses were based on values centered on six locations including Peace River, Alberta $\left(56.25^{\circ} \mathrm{N} ; 117.25^{\circ} \mathrm{W}\right)$, Lethbridge, Alberta $\left(49.75^{\circ} \mathrm{N}\right.$; $\left.112.75^{\circ} \mathrm{W}\right)$, Red Deer, Alberta $\left(52.25^{\circ} \mathrm{N} ; 113.75^{\circ} \mathrm{W}\right)$, Saskatoon, Saskatchewan $\left(52.25^{\circ} \mathrm{N} ; 106.75^{\circ} \mathrm{W}\right)$, Regina, Saskatchewan $\left(50.25^{\circ} \mathrm{N} ; 104.75^{\circ} \mathrm{W}\right)$, and Winnipeg, Manitoba $\left(49.75^{\circ} \mathrm{N} ; 97.25^{\circ} \mathrm{W}\right)$.

Sensitivity analysis was conducted to quantify the response of $S$. lineatus to changes in precipitation and temperature. Incremental scenarios were developed to reflect the possible range of temperature and precipitation values that could be expected to occur in Europe and Canada, based on current climate. Scenarios were selected, based on potential variation of present climate. EI values, based on current climate, were compared to scenarios that differed by -2 , $-1,+1$, and $+2^{\circ} \mathrm{C}$ from current temperatures (maximum 
TABle 1: Descriptions of CLIMEX parameters and parameter values used to predict the potential distribution and relative abundance of Sitona lineatus in North America.

\begin{tabular}{|c|c|c|c|}
\hline Index & Parameter & Description & Value \\
\hline \multirow[t]{4}{*}{ Temperature } & DV0 & Limiting low temperature & $7.0^{\circ} \mathrm{C}$ \\
\hline & DV1 & Lower optimal temperature & $16.0^{\circ} \mathrm{C}$ \\
\hline & DV2 & Upper optimal temperature & $25.0^{\circ} \mathrm{C}$ \\
\hline & DV3 & Limiting high temperature & $32.0^{\circ} \mathrm{C}$ \\
\hline \multirow[t]{4}{*}{ Moisture } & SM0 & Limiting low soil moisture & 0.10 \\
\hline & SM1 & Lower optimal soil moisture & 0.40 \\
\hline & SM2 & Upper optimal soil moisture & 1.00 \\
\hline & SM3 & Limiting high moisture & 1.50 \\
\hline \multirow[t]{5}{*}{ Diapause } & DPD0 & Diapause induction day length & $14 \mathrm{~h}$ \\
\hline & DPT0 & Diapause induction temperature & $11.0^{\circ} \mathrm{C}$ \\
\hline & DPT1 & Diapause termination temperature & $3.0^{\circ} \mathrm{C}$ \\
\hline & DPD & Diapause development days & 120 \\
\hline & DPSW & Diapause indicator for winter diapause & 0 \\
\hline \multirow[t]{2}{*}{ Cold Stress } & TTCS & Cold stress threshold & $-14.0^{\circ} \mathrm{C}$ \\
\hline & THCS & Cold stress temperature rate & -0.00025 \\
\hline \multirow[t]{2}{*}{ Heat Stress } & TTHS & Heat stress temperature threshold & $34.0^{\circ} \mathrm{C}$ \\
\hline & THHS & Heat stress temperature rate & 0.002 \\
\hline \multirow[t]{2}{*}{ Dry Stress } & SMDS & Dry stress threshold & 0.02 \\
\hline & HDS & Dry stress rate & -0.003 \\
\hline \multirow[t]{2}{*}{ Wet Stress } & SMWS & Wet stress threshold & 2.0 \\
\hline & HWS & Wet stress rate & 0.01 \\
\hline \multicolumn{4}{|c|}{ Day-degree accumulation above DV0 } \\
\hline & DV0 & & 7.0 \\
\hline & DV3 & & 32.0 \\
\hline \multicolumn{4}{|c|}{ Day-degree accumulation above DV3 } \\
\hline & DV3 & & 32.0 \\
\hline & DV4 & & 100 \\
\hline \multicolumn{4}{|c|}{ Day-degree accumulation above DVCS } \\
\hline & DVCS & & 8.0 \\
\hline & DV4 & & 100 \\
\hline \multicolumn{4}{|c|}{ Degree-days per generation } \\
\hline & PDD & Minimum degree days above DV0 to complete generation & 450 \\
\hline
\end{tabular}

and minimum monthly values) and precipitation values (monthly total) that were $-40,-20,+20$, and $+40 \%$ of current values. The comparison was conducted for five locations within the major pulse crop production region of western Canada (Table 2). The locations were selected to provide a range of EI values $(\mathrm{EI}=22-36)$.

Contour maps were generated by importing CLIMEX output into ArcView 8.1 [33]. Ecoclimatic Index values were displayed in five categories: "Unfavourable" (0-5), "Suitable" (5-10), "Marginal" (5-10)"Favourable" (15-20), and "Very Favourable" (>20). The "Suitable" and higher categories represent areas that may experience pest outbreaks of $S$. lineatus. Actual densities will be dependent on meteorological conditions that differ from long-term climate normals. The "Favourable" and "Very Favourable" categories describe meteorological conditions, similar to long-term climate normals, in which outbreaks resulting in crop damage may occur.

\section{Results and Discussion}

3.1. Model Development. In Europe, Hans [23] reported that overwintered $S$. lineatus adults become active when temperatures exceed $4.5^{\circ} \mathrm{C}$. Flight was found to occur when temperatures were greater than $12.5^{\circ} \mathrm{C}[6]$. In North America, Prescott and Reeher [22] observed that overwintered adults began spring flight in March, when maximum temperatures were $57^{\circ} \mathrm{F}\left(13.9^{\circ} \mathrm{C}\right)$ or greater. In Idaho, USA, Fisher [21] reported that adult flight occurred between April 25 and May 19 and adult flights, out of the host crop, occurred in late July and August. 
TABLE 2: Effect of changes in mean annual precipitation $(-40 \%$ to $+40 \%)$ and temperature $(-2$ to +2$)$ from current values on Ecoclimatic Indices for Sitona lineatus at five locations.

\begin{tabular}{lccccccccccc}
\hline & & & \multicolumn{3}{c}{ Current } & \multicolumn{3}{c}{ Change in mean precipitation (\%) } & \multicolumn{3}{c}{ Change in mean temperature (C) } \\
Location & Latitude & Longitude & Climate & -40 & -20 & +20 & +40 & -2 & -1 & +1 & +2 \\
\hline Lethbridge, Alberta & $49.69^{\circ}$ & $-112.83^{\circ}$ & 11 & 3 & 7 & 16 & 19 & 10 & 11 & 11 & 10 \\
Red Deer, Alberta & $52.27^{\circ}$ & $-113.80^{\circ}$ & 21 & 10 & 17 & 22 & 22 & 14 & 18 & 24 & 26 \\
Regina, Saskatchewan & $50.44^{\circ}$ & $-104.61^{\circ}$ & 11 & 3 & 7 & 15 & 19 & 10 & 11 & 10 & 9 \\
Saskatoon, Saskatchewan & $52.15^{\circ}$ & $-106.65^{\circ}$ & 10 & 2 & 6 & 14 & 19 & 10 & 9 & 9 & 8 \\
Winnipeg, Manitoba & $49.89^{\circ}$ & $-97.15^{\circ}$ & 20 & 8 & 14 & 22 & 22 & 18 & 20 & 20 & 18 \\
\hline
\end{tabular}

In Europe, oviposition was found to occur when the daily mean temperature is $12^{\circ} \mathrm{C}$ and the daily temperature must rise above $13^{\circ} \mathrm{C}$ for some hours [34]. In Idaho, USA, oviposition occurred during May [21]. Prescott and Reeher [22] reported that in the Pacific Coastal region of North America oviposition can occur between February and May. Lerin [26] reported that it took 70 days for eggs to hatch at $8^{\circ} \mathrm{C}$ and 6.2 days at $29^{\circ} \mathrm{C}$. Development was linear up to $25^{\circ} \mathrm{C}$ and only one day difference between 25 and $30.5^{\circ} \mathrm{C}$. Egg mortality was negligible at $30^{\circ} \mathrm{C}, 26 \%$ at $32^{\circ} \mathrm{C}$, and $100 \%$ at $33^{\circ} \mathrm{C}$. In England, larvae were collected on May 21 and in Scotland larvae were collected as late as July 24 [24]. In Idaho, USA, pupae required 14-18 days to complete development and pupae occurred from early July to early August [21]. In England, late summer flights began soon after adults emerged from pupal cells during late July, with flights continuing until mid-October [6].

The model was developed to produce output that fitted with reported results, based on phenology and distribution for Britain, Denmark, France, Germany, Switzerland, Norway, and The Netherlands. Limiting lower temperature (DV0) values between 4 and $12^{\circ} \mathrm{C}$ were iteratively tested and a value of $7^{\circ} \mathrm{C}$ provided the best fit with distributions and phenologies in Europe. Similarly, values for optimal and limiting high temperatures (DV1, DV2, DV3) were incrementally adjusted in order to develop a model that matched reported distributions and phenologies for Europe (Table 1).

Soil moisture indices (SM0, SM1, SM2, SM3) reflected the assumption that soil moisture is a significant factor that is related to plant moisture content and microclimatic conditions [14]. The moisture index was based on computed weekly soil moisture levels. This species, particularly larval stages, appears to prefer moist conditions. High temperatures and dry soil resulted in mortality rates of eggs and larvae reaching $85 \%$ [21]. Andersen [34] reported that survival of first instar larvae was 5.5 days at $100 \% \mathrm{RH}$ and $9^{\circ} \mathrm{C}$ but dropped to 1.5 days at $100 \% \mathrm{RH}$ and $26^{\circ} \mathrm{C}$. When relative humidity dropped below $90 \%\left(15^{\circ} \mathrm{C}\right)$, all larvae died within 5 hours. Limiting low soil moisture (SM0) was set at 0.1 . The lower optimal moisture was increased to 0.4 from 0.3 and the upper optimal moisture level (SM2) was set at 1.0 and SM3 was set at 1.5 to permit saturation that may occur in irrigated fields (Table 1).

CLIMEX uses both photoperiod and temperature as inputs for determination of induction and temperature for termination of diapause. Simulations indicated that an induction day length of 14 hours provided the best fit to results reported for Britain, Denmark, Germany, and Idaho (USA) $[21,23,24]$. Final diapause values for induction day length (DPDO), diapause induction temperature (DPTO), diapause termination temperature (DPT1), and required days for diapause development (DPD) were set at 14, 11, 3, and 120, respectively. The known distribution of $S$. lineatus seemed to indicate a greater diversity of diapause behaviour than could be accounted for with the model parameters. As a result, the parameters were adjusted to reflect the weevil's patterns in its core distribution (i.e., north of $45^{\circ}$ latitude in Europe) (Table 1).

Stress values, related to the ability of the species to survive adverse conditions, were set to limit geographical distributions. Cold stress limits were assigned at a level to reflect the occurrence of $S$. lineatus in northern countries such as Denmark, Finland, and Sweden. Selected values were similar to values for the pollen beetle, Meligethes viridescens (Fabricius) [19]. Sitona lineatus occurs across southern Europe, central Asia, and Africa. The rate of heat stress accumulation (THHS) was set in order to permit distribution across these regions.

3.2. Model Validation. Lower limiting temperature (DV0) values between 4 and $12^{\circ} \mathrm{C}$ were iteratively tested and a value of $7^{\circ} \mathrm{C}$ provided the best fit with distribution and growing season phenology in Europe. Similarly values for DV1, DV2, and DV3 were incrementally adjusted in order to develop a model that matched reported distributions and phenologies for Europe.

Predicted distribution of S. lineatus in Europe (Figure 1) agreed with the extensive distribution data reported from Fauna Europaea Web Service [1], Botha et al. [2], and Hoebeke and Wheeler Jr. [3]. The model did not predict that S. lineatus would occur in Egypt or Saudi Arabia. Output suggested that soil moistures were too dry and that diapause would not occur, resulting in $\mathrm{EI}=0$. Application of irrigation scenarios indicated that soil moisture values could be raised to suitable values. Diapause (based on day length) still proved to be limiting. The model predicted that some locations with climates where $S$. lineatus does not currently occur are suitable for establishment of this species. For example, the model predicted that climates in Australia, New Zealand, China, Ethiopia, Kenya, and Tanzania could support S. lineatus populations. 


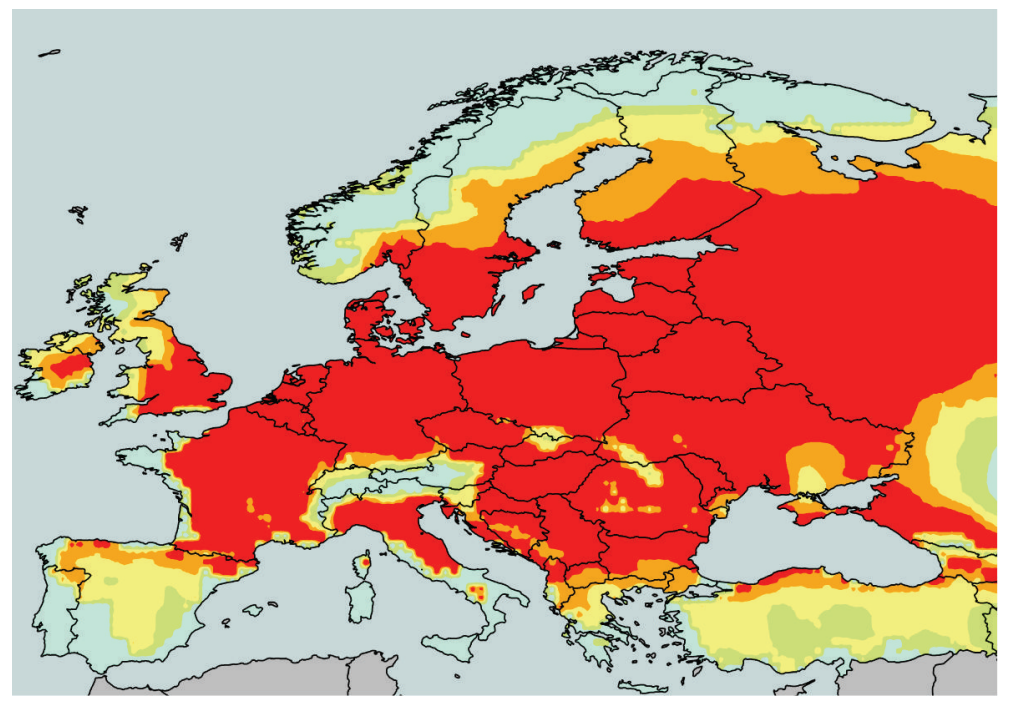

Figure 1: Potential distribution and relative abundance of Sitona lineatus in Europe as predicted by CLIMEX. Light blue: "Unfavourable" $(\mathrm{EI}=0-5)$; Green: "Marginal" (EI = 5-10); Yellow: "Suitable" (EI = 10-15); Tan: "Favourable" (EI = 15-20); Red: "Very Favourable" $(\mathrm{EI}>20)$.

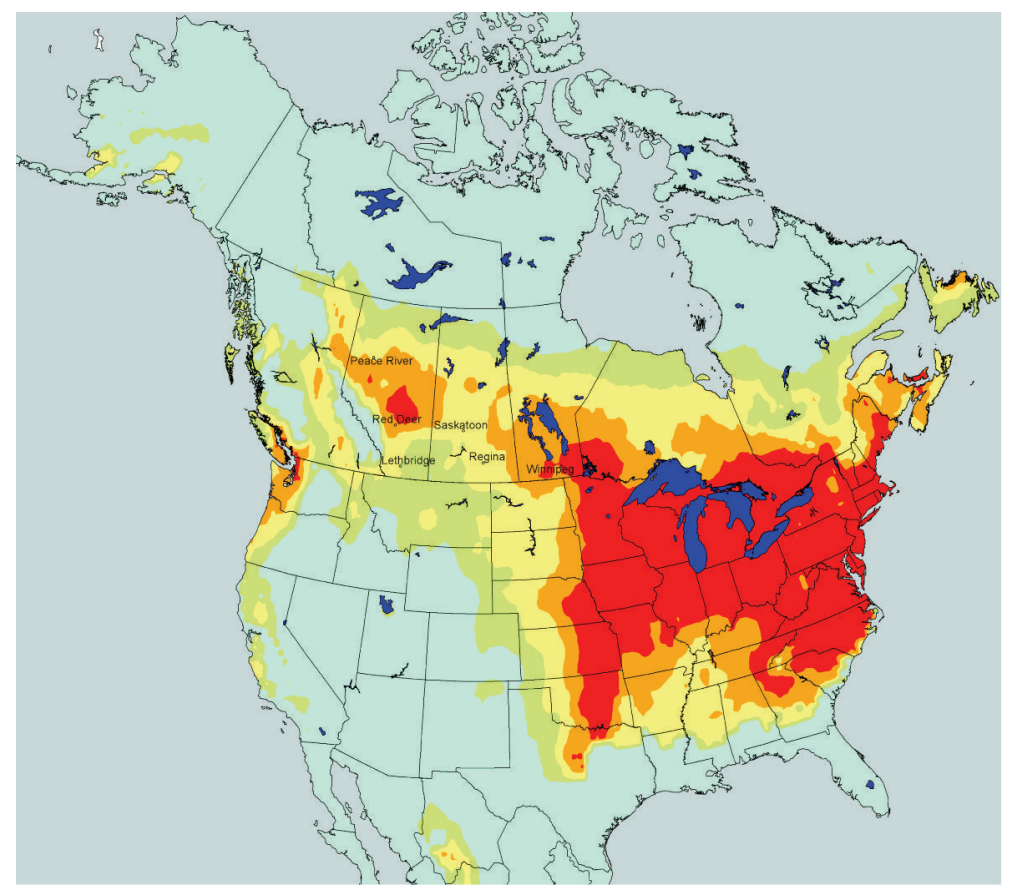

FIgure 2: Potential distribution and relative abundance of Sitona lineatus in North America as predicted by CLIMEX under current climate conditions. Dark blue: lakes; Light blue: "Unfavourable" (EI = 0-5); Green: "Marginal" (EI = 5-10); Yellow: "Suitable" (EI = 10-15); Tan: "Favourable" (EI = 15-20); Red: "Very Favourable" (EI > 20).

In North America, predicted distributions (Figure 2) in the province of British Columbia, Canada, and the States of Washington, Oregon, Idaho, California, and Virginia in the USA agree with reported distributions [3]. Model output also predicted that $S$. lineatus could become established in the Prairie Ecozone of western Canada and agreed with population surveys in Alberta and Saskatchewan that have been conducted since 2001 [27]. Further, the model indicated that EI values would be greater in regions north of the current geographic range of S. lineatus. Moisture Index (MI) values were shown to be less than optimal, indicating that precipitation in southern Alberta was less than optimal. Rainfall, between late June and August, was minimal, relative to the species requirements. Ecoclimatic Index values near Red Deer were higher. The increased EI values were associated with higher MI values. Rainfall 
amounts for the period of June to August were greater than those that were reported for Lethbridge. Dry moisture conditions could have a negative impact on both larval and pupal survival [4].

Model predictions for phenology agreed with published reports. Early season activity of S. lineatus is of particular interest. At Rothamsted, England, adults were first collected from late March until mid-April [6]. Our model predicted that first flights would occur in early April. In Kent, England adults were observed in peas in late March [24] and these dates were similar to the model prediction of March 22. Jackson [24] also stated that adult appearance was delayed by two weeks (April 8) during a cool spring. The model was run with a scenario in which the temperature was reduced by $1^{\circ} \mathrm{C}$ and adults were predicted to first become active on April 12. In Denmark, the model predicted that adults would become active in mid-April. This result was in agreement with data presented by Nielson and Jensen [20]. In Canada, adults first appeared in pea fields in June of 2007, and peak larval counts occurred on June 8 at Lethbridge, Alberta. [8]. It is likely that adults were active before this time. The weekly growth index suggested that $S$. lineatus would be highest in early to midJune.

The model predicted that the potential range of $S$. lineatus could extend well beyond current distributions along western and eastern seaboards in North America. Areas in southern Ontario, Quebec, and eastern USA were also predicted to be at risk. Current areas of Canadian pulse production include Quebec and Ontario (a wide selection of coloured beans and the white navy bean), Manitoba (white and coloured beans, pea, and lentil), Saskatchewan (pea, lentil, and chickpea and some bean), and Alberta (beans, pea, lentil, and chickpea) [35].

3.3. Sensitivity Analysis. Sensitivity analyses were conducted to measure EI response to changes in temperature and precipitation. Model output indicated that S. lineatus was more sensitive to changes in precipitation (Figure 3) than temperature, indicating that the five locations (climate) were dryer than optimal moistures and temperatures within the Prairie Ecosystem were generally suitable for this species. The model also indicated that sensitivity was location specific. Varying temperatures from -2 to $+2^{\circ} \mathrm{C}$ from current longterm normals revealed that the Lethbridge, Regina, Saskatoon, and Winnipeg locations were not sensitive to temperature changes (Table 2). That is, EI values showed marginal changes. Temperatures at these locations are between lower and upper optimal temperature parameters (DV1 and DV2). Ecoclimatic Index values at Red Deer did show a linear effect with increasing temperatures, increasing from EI $=14$ to $\mathrm{EI}=26$ with incremental temperature increases. The results suggest that $S$. lineatus populations may increase, in areas north of Calgary, in warmer growing seasons. The S. lineatus model also demonstrated a linear response in EI values to increased precipitation amounts (Table 3). The model predicted that EI values near Saskatoon would increase from $\mathrm{EI}=2(40 \%$ less than long-term normal climate data) to $\mathrm{EI}=19$ with wetter than average weather $(+40 \%)$.
Sensitivity analysis was also conducted to compare spatial response of EI values to variations in temperature and precipitation. For current climate, EI values were relatively low. Categories were set for EI $=10$ (low), 15, and 20. This analysis was conducted for all five locations within the Prairie Ecosystem ( $n=3420$ grid cells) and also specifically for areas in central and southern Alberta ( $n=456$ grid cells). Responses were similar across both scales and agreed with location specific trends (Tables 3 and 4). Ecoclimatic Index values increased from temperatures that were $2^{\circ} \mathrm{C}$ below long-term normals back up to long-term normal levels. Temperatures warmer than long-term normals appeared to have little effect on EI values. Results suggest that moist conditions would be conducive to large populations (i.e., compared to cool or dry conditions). Under climate conditions that were $40 \%$ wetter than long-term normals, the model predicted that 47\% (Prairie Ecosystem) and 39\% (Alberta) of the spatial area could expect to have EI = 20 or greater (Tables 3 and 4; Figure 3). Across southern Saskatchewan and Alberta, the model predicted that EI values would be reduced for dryer than normal conditions (Figure 3(a)).

Compared to climate data (long-term normals), sensitivity analysis results suggest that $S$. lineatus should respond less favourably in dry seasons and more favourably in wetter seasons. This conclusion may be based on conditions that occurred in the previous summer. That is, late May to July rainfall may be an important factor that determines midsummer survival and potential number of adults available for the following season. For example, the number of notches per plant $(>27)$ from locations near Lethbridge was greatest in 2006 [8]. Though the 2006 growing season (April-August) was dry, April and May were wetter than normal [36]. Also, the 2005 growing season was much wetter than normal. The model would predict that these conditions would be conducive for population increase. Across most of Alberta, numbers declined dramatically between 2007 and 2008 [37, 38]. This may have been due to exceptionally dry periods during June, July, and August in 2007. In 2008, April and early May were exceptionally dry near Lethbridge [36]. Dry conditions may have reduced larval and pupal survival. Though $S$. lineatus was first collected in fields around Lethbridge in 1997, only sporadic damage was reported in the early 2000s. The region experienced a severe drought between 2001 and 2003 [36]. Increasing outbreak levels and geographic expansion throughout southern Alberta were experienced in 2006 and 2007 (reported in Saskatchewan as well) when several thousands of hectares of field peas were sprayed [8]. Low densities and associated sporadic damage may have been associated with the hot dry conditions and increased damage/range expansion may be explained by increased moisture levels experienced between 2004 and 2008.

3.4. General Circulation Model Analyses. Bioclimatic model output varied for each of the three GCMs (Figures 4, 5 and 6). In terms of EI values, the NCAR273 CCSM climate data resulted in the most significant increase in northern regions. Application of this GCM predicted that S. lineatus would 


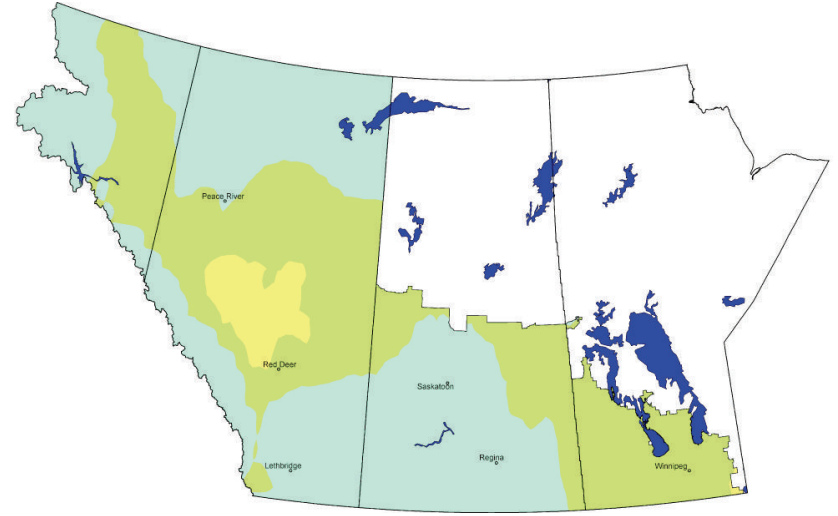

(a)

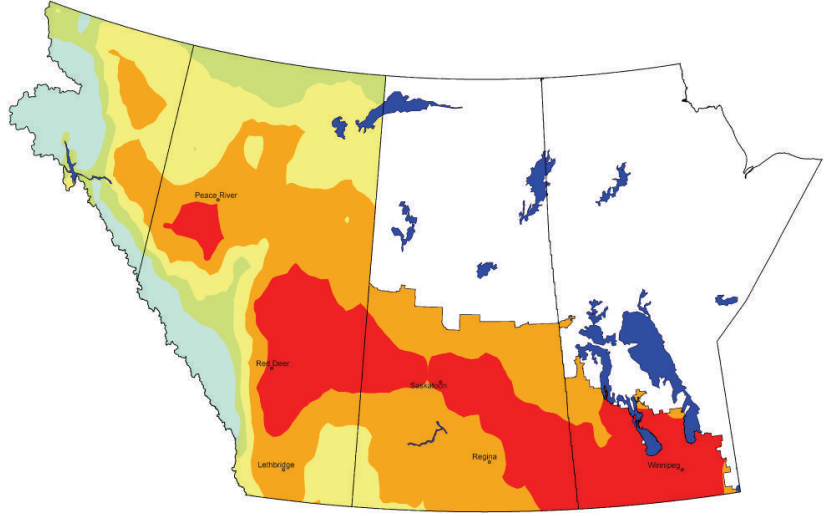

(b)

FIGURE 3: Predicted Ecoclimatic Index (EI) values with precipitation $40 \%$ less (a) and 40\% greater (b) than current climate. Dark blue: lakes; Light blue: "Unfavourable" (EI = 0-5); Green: "Marginal" (EI = 5-10); Yellow: "Suitable" (EI = 10-15); Tan: "Favourable" (EI = 15-20); Red: "Very Favourable" (EI > 20).

TABLE 3: Effect of changes in temperature and precipitation from current climate on Ecoclimatic Index (EI) values for Sitona lineatus across all locations within the Prairie Ecosystem ( $n=3420$ grid cells). The values are expressed as a percentage of total geographic area.

\begin{tabular}{|c|c|c|c|c|}
\hline Variable & Scenario & $\mathrm{EI} \geq 10$ & $\mathrm{EI} \geq 15$ & $\mathrm{EI} \geq 20$ \\
\hline & Current climate & $85.7 \%$ & $51.1 \%$ & $13.5 \%$ \\
\hline Temperature & $-2^{\circ} \mathrm{C}$ & $79.9 \%$ & $20.5 \%$ & $0.1 \%$ \\
\hline Temperature & $-1^{\circ} \mathrm{C}$ & $86.3 \%$ & $37.9 \%$ & $3.9 \%$ \\
\hline Temperature & $+1^{\circ} \mathrm{C}$ & $82.3 \%$ & $54.7 \%$ & $17.0 \%$ \\
\hline Temperature & $+2^{\circ} \mathrm{C}$ & $78.8 \%$ & $51.2 \%$ & $15.8 \%$ \\
\hline Precipitation & $-40 \%$ & $2.8 \%$ & $0.0 \%$ & $0.0 \%$ \\
\hline Precipitation & $-20 \%$ & $52.3 \%$ & $10.4 \%$ & $0.2 \%$ \\
\hline Precipitation & $+20 \%$ & $98.4 \%$ & $81.5 \%$ & $32.4 \%$ \\
\hline Precipitation & $+40 \%$ & $99.8 \%$ & $93.7 \%$ & $47.4 \%$ \\
\hline
\end{tabular}

TABLE 4: Effect of changes in temperature and precipitation from current climate on Ecoclimatic Indices (EIs) for Sitona lineatus in southern and central Alberta $(n=456$ grid cells). Values are \% of total area. The values are expressed as a percentage of total geographic area in this region.

\begin{tabular}{|c|c|c|c|c|}
\hline Variable & Scenario & $\mathrm{EI} \geq 10$ & $\mathrm{EI} \geq 15$ & $\mathrm{EI} \geq 20$ \\
\hline & Current climate & $56.6 \%$ & $15.1 \%$ & $2.2 \%$ \\
\hline Temperature & $-2^{\circ} \mathrm{C}$ & $49.1 \%$ & $2.6 \%$ & $0.0 \%$ \\
\hline Temperature & $-1^{\circ} \mathrm{C}$ & $57.0 \%$ & $9.0 \%$ & $0.0 \%$ \\
\hline Temperature & $+1^{\circ} \mathrm{C}$ & $53.1 \%$ & $17.5 \%$ & $2.6 \%$ \\
\hline Temperature & $+2^{\circ} \mathrm{C}$ & $48.2 \%$ & $15.1 \%$ & $3.3 \%$ \\
\hline Precipitation & $-40 \%$ & $0.9 \%$ & $0.0 \%$ & $0.0 \%$ \\
\hline Precipitation & $-20 \%$ & $15.6 \%$ & $1.8 \%$ & $0.0 \%$ \\
\hline Precipitation & $+20 \%$ & $92.8 \%$ & $51.3 \%$ & $11.4 \%$ \\
\hline Precipitation & $+40 \%$ & $99.6 \%$ & $82.0 \%$ & $39.0 \%$ \\
\hline
\end{tabular}

be very abundant north of $53^{\circ} \mathrm{N}$. Similar, though slightly lower, EI values were predicted for the CSIRO MARK 3.0 and MIROC-H GCM climates. The three GCMs also resulted in varying output across the Prairie Ecosystem. NCAR273 climate data resulted in suitable to very favourable EI values while the CSIRO MARK 3.0 data resulted in some areas being categorized as marginal to suitable. The model predicted that south eastern Alberta and a large area of southern Saskatchewan would be marginal when the MIROC-H GCM was applied. Results of this study suggest that species responses are specific not only to GCM but also to specific regions across North America. Olfert et al. [39] assessed the impact of GCMs on Melanoplus sanguinipes (Fabricius) distribution and abundance. Their study was based on 


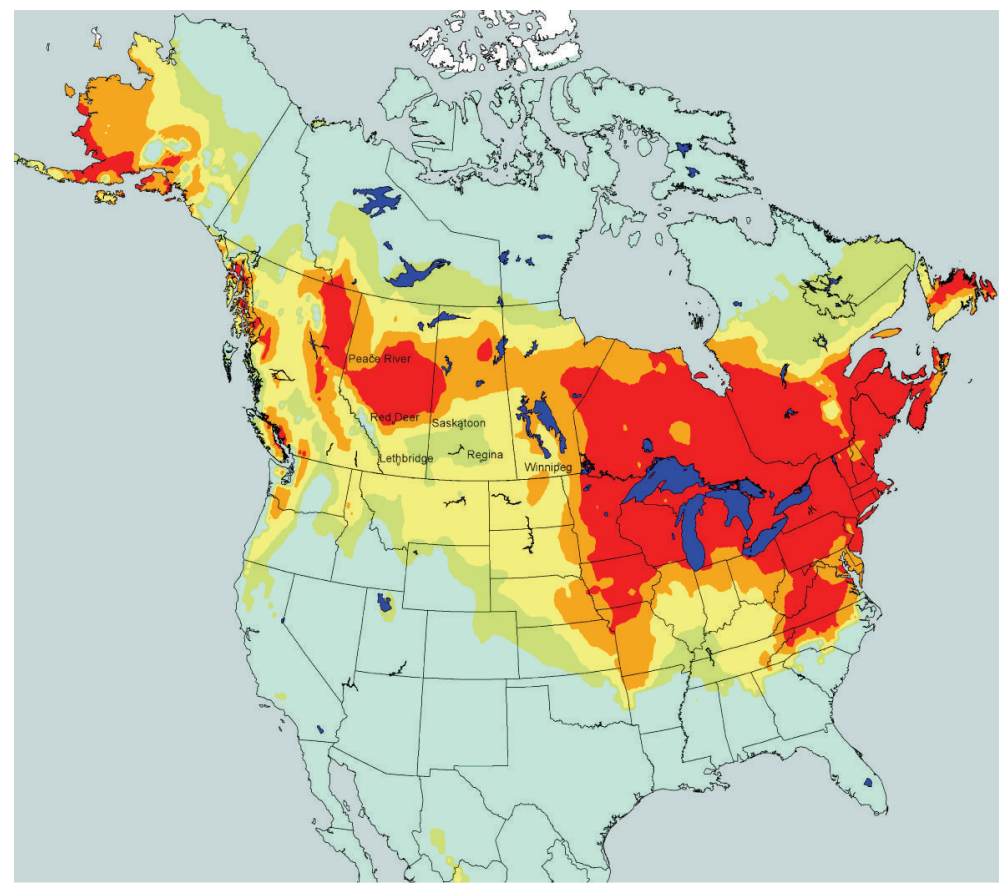

FIgURE 4: Potential distribution and relative abundance of Sitona lineatus in North America for 2080 as predicted by CLIMEX and the CSIRO Mark 3.0 climate change projection. Dark blue: lakes; Light blue: "Unfavourable" (EI = 0-5); Green: "Marginal” (EI = 5-10); Yellow: "Suitable" (EI = 10-15); Tan: "Favourable" (EI = 15-20); Red: "Very Favourable" (EI > 20).

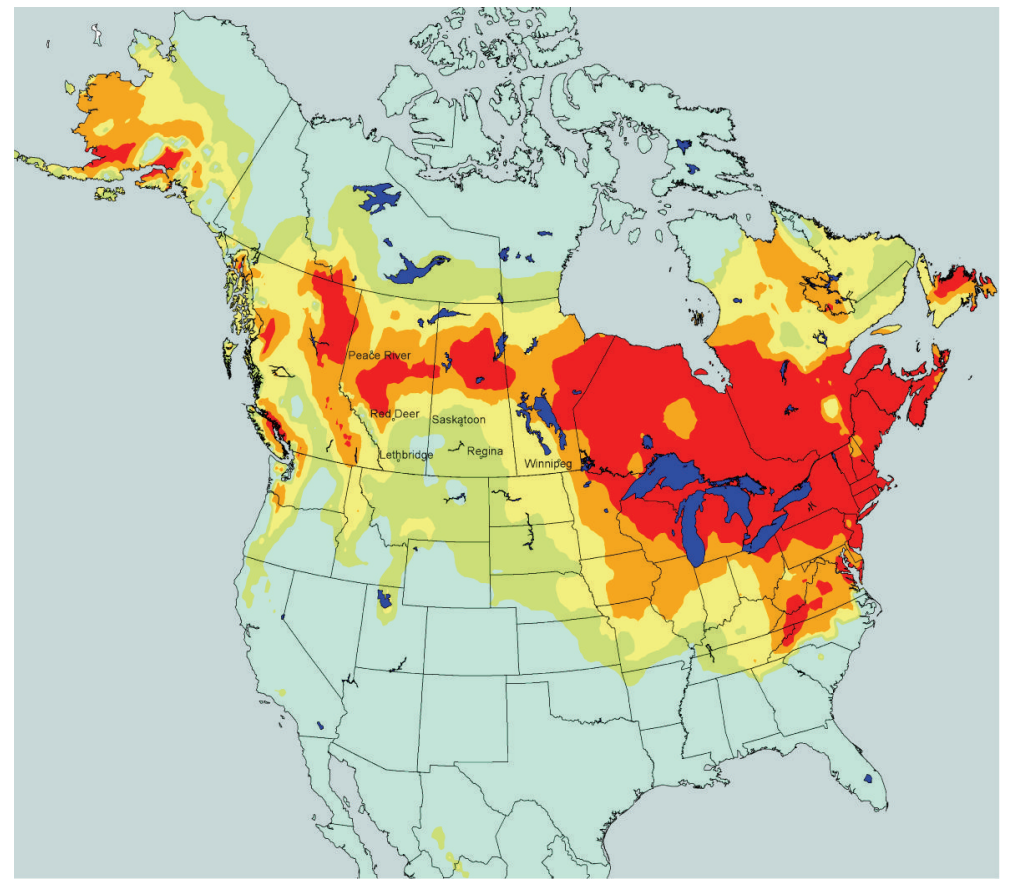

FIgure 5: Potential distribution and relative abundance of Sitona lineatus in North America for 2080 as predicted by CLIMEX and the MIROC-H climate change projection. Dark blue: lakes; Light blue = "Unfavourable" (EI = 0-5); Green: "Marginal" (EI = 5-10); Yellow: "Suitable" (EI = 10-15); Tan: "Favourable" (EI = 15-20); Red: "Very Favourable" (EI > 20). 


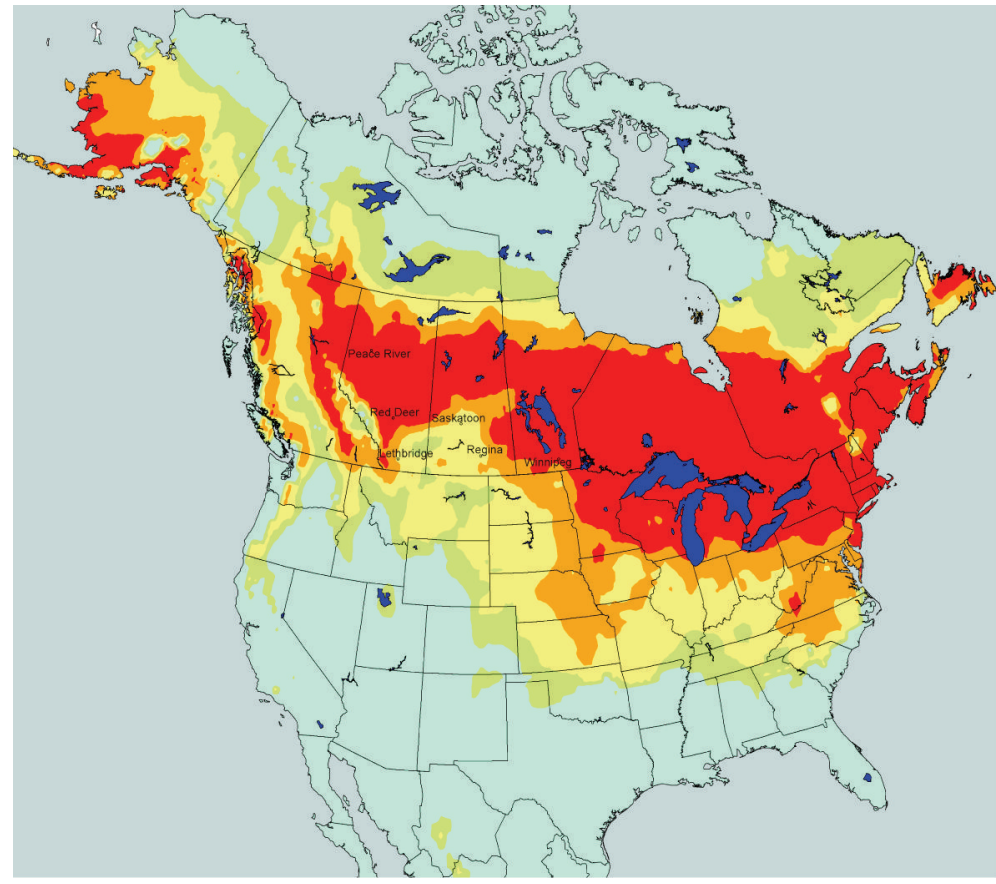

FIgure 6: Potential distribution and relative abundance of Sitona lineatus in North America for 2080 as predicted by CLIMEX and the NCAR273 CCSM climate change projection. Dark blue: lakes; Light blue: "Unfavourable" (EI = 0-5); Green: "Marginal" (EI = 5-10); Yellow: "Suitable" (EI = 10-15); Tan: "Favourable" (EI = 15-20); Red: "Very Favourable" (EI > 20).

TABLE 5: Baseline (Current climate: CRU) and General Circulation Model scenarios (CSIRO MARK 3.0, MIROC-H, NCAR273 CCSM) and resulting changes to mean Ecoclimatic Index (EI) values for Sitona lineatus at six defined regions (geographic rectangle, $4^{\circ}$ latitude by $7^{\circ}$ longitude) in western Canada.

\begin{tabular}{lcccccc}
\hline Location & Latitude & Longitude & Current climate (CRU) & CSIRO Mark 3.0 & MIROC-H & NCAR273 CCSM \\
\hline Lethbridge Alberta & $49.75^{\circ}$ & $-112.75^{\circ}$ & 9 & 13 & 6 & 13 \\
Peace River Alberta & $56.25^{\circ}$ & $-117.25^{\circ}$ & 13 & 14 & 13 & 21 \\
Red Deer Alberta & $52.25^{\circ}$ & $-113.75^{\circ}$ & 20 & 21 & 8 & 13 \\
Regina Saskatchewan & $50.25^{\circ}$ & $-104.75^{\circ}$ & 10 & 8 & 6 & 6 \\
Saskatoon Saskatchewan & $52.25^{\circ}$ & $-106.75^{\circ}$ & 11 & 14 & 14 & 11 \\
Winnipeg Manitoba & $49.75^{\circ}$ & $-97.25^{\circ}$ & 20 & & 22 \\
\hline
\end{tabular}

the three GCMs that were used in the current study and they found that response of $M$. sanguinipes not only varied by GCM but also was region specific. Mika et al. [13] reported that effect of climate change differed strongly between GCMs and that EI differences for Contarinia nasturtii were greatest for regions that were categorized as "very favourable" (EI = 30).

The relational database was queried to analyze the impact of climate change for six locations in western Canada (Table 5). Model output based on NCAR273 CCSM resulted in EI increases at each of the locations with the greatest increases at Red Deer and Peace River. The CSIRO MARK 3.0 resulted in EI increases for Lethbridge, Red Deer, and Peace River and decreased EI values for the remaining three locations. Model output based on MIROC-H climate data resulted in reduced EI values for five of the six locations. Peace River was predicted to have an EI value that was the same as for current climate.
TABLE 6: Effect of changes in precipitation (expressed as a percentage of total geographic area) from current values on Ecoclimatic Indices for Sitona lineatus across North America for CRU (current climate) and general circulation model (CSIRO MARK 3.0, MIROC-H, NCAR273 CCSM) scenarios.

\begin{tabular}{lccc}
\hline Scenario & EI $\geq 10$ & EI $\geq 15$ & EI $\geq 20$ \\
\hline Current climate (CRU) & $25.2 \%$ & $17.1 \%$ & $9.8 \%$ \\
CSIRO Mark 3.0 & $37.5 \%$ & $25.5 \%$ & $15.2 \%$ \\
MIROC-H & $34.6 \%$ & $22.9 \%$ & $13.1 \%$ \\
NCAR273 CCSM & $37.4 \%$ & $26.2 \%$ & $17.3 \%$ \\
\hline
\end{tabular}

Analysis was conducted to compare changes in EI values, as a result of climate change, across North America (Table 6). Compared to current climate, model output indicates that the area of the continent that will have EI values greater than 10 will increase by $37-48 \%$. Model runs showed that areas 
with EI $>20$ could increase by 33\% (MIROC-H), 54\% (CSIRO MARK 3.0), and 76\% (NCAR273 CCSM). These results were similar to values reported by Olfert and Weiss [40] who indicated that $\mathrm{a}+3^{\circ} \mathrm{C}$ increase in temperature would result in $19.7 \%$ to $47.1 \%$ increase in areas with EI $>20$ for Ceutorhynchus obstrictus (Marsham), Oulema melanopus L., and Meligethes viridescens (Fabricius).

\section{Conclusions}

Some cautions have been expressed regarding the utilization of bioclimatic models for investigating the potential impact of climate on insect populations. For example, adaptation is likely to occur with the result that biotic interactions may not remain the same over time, and genetic and phenotypic composition of populations may change [41]. In addition, most insect species have some limitation to dispersal [42]. In the instance of $S$. lineatus, the impact of biotic factors such as natural enemies (e.g., diseases, parasites, predators) and host plant resistance and other abiotic factors, such as intercropping and chemical insecticides, must also be considered [4]. So even though model results suggest conditions in some regions to be conducive to $S$. lineatus populations under climate change, these additional biotic and abiotic factors could result in population decline. In these instances, bioclimate and GCMs may not account for changes in population and may overestimate populations.

To address these naturally occurring phenomena, bioclimatic modeling of $S$. lineatus populations would benefit from multitrophic studies (host plants-S. lineatus - natural enemies). For example, Cárcamo et al. [9] suggested that when adults lay eggs on plants past the 5th node stage, larval recruitment was lower compared to oviposition at the 2nd node stage. As a result, cooler growing conditions in the spring may delay $S$. lineatus invasions into fields until the crops are more advanced. Warmer temperatures may improve the synchrony between insect and plant.

Sitona lineatus is expected to continue to expand its range; as a result Vankosky et al. [4] suggested that an integrated approach of intercropping, host plant resistance, predators, parasitoids, pathogens, and chemical insecticides would be required to successfully manage this recently introduced pest species. In an effort to provide advance warnings of continued range expansion a region wide monitoring program has been initiated across western Canada [43].

\section{Acknowledgments}

The authors would like to acknowledge C. Herle and S. Barkley for their technical support and D. Giffen for preparation of the maps.

\section{References}

[1] F. Europaea, http://www.faunaeur.org.

[2] J. Botha, D. Hardie, and F. Casella, "The pea leaf weevil, Sitona lineatus: exotic threat to Western Australia," Government of Western Australia Department of Agriculture Factsheet 11, Government of Western Australia Department of Agriculture, Perth, Australia, 2004.
[3] E. R. Hoebeke and A. G. Wheeler Jr., "Sitona lineatus (L.), the pea leaf weevil: first records in eastern North America (coleoptera: curculionidae)," Proceedings of the Entomological Society of Washington, vol. 87, no. 2, pp. 216-220, 1985.

[4] M. Vankosky, L. M. Dosdall, and H. A. Cárcamo, "Distribution, biology and integrated management of the pea leaf weevil, Sitona lineatus L. (Coleoptera: Curculionidae), with an analysis of research needs," CAB Reviews, vol. 4, no. 7, pp. 1$18,2009$.

[5] B. S. Nielsen, "Yield responses of Vicia faba in relation to infestation levels of Sitona lineatus L. (Col., Curculionidae)," Journal of Applied Entomology, vol. 110, no. 3, pp. 398-407, 1990.

[6] N. Hamon, R. Bardner, L. Allen-Williams, and J. B. Lee, "Flight periodicity and infestation size of Sitona lineatus," Annals of Applied Biology, vol. 111, no. 2, pp. 271-284, 1987.

[7] F. Landon, J. Levieux, J. Huignard, D. Rougan, and P. Taupin, "Feeding activity of Sitona lineatus L. (Col., Curculionidae) on Pisum sativum L. (Leguminosae) during its imaginal life," Journal of Applied Entomology, vol. 19, no. 7, pp. 515-522, 1995.

[8] H. A. Cárcamo and S. Meers, "The first insect pest of pulse crops in Alberta: the pea leaf weevil," Agronomy Update, vol. 2007, pp. 82-88, 2007.

[9] H. A. Cárcamo, M. A. Vankosky, C. Herle, K. Coles, S. Meers, and O. Olfert, "Integrated management of the pea leaf weevil in pea fields," Final Report for ACIDF, Alberta and Saskatchewan Pulse Grower Commissions, and AAFCMatching Investment Initiative, 2010.

[10] M. A. Vankosky, H. A. Cárcamo, and L. M. Dosdall, "Identification of potential natural enemies of the pea leaf weevil, Sitona lineatus L. in western Canada," Journal of Applied Entomology, vol. 135, no. 4, pp. 293-301, 2011.

[11] M. A. Vankosky, H. A. Cárcamo, R. H. McKenzie, and L. M. Dosdall, "Integrated management of Sitona lineatus with nitrogen fertilizer, Rhizobium, and thiamethoxam insecticide," Agronomy Journal, vol. 103, no. 2, pp. 565-572, 2011.

[12] H. G. Andrewartha and L. E. Birch, The Distribution and Abundance of Animals, University of Chicago Press, Chicago, Ill, USA, 1954.

[13] A. M. Mika, R. M. Weiss, O. Olfert, R. H. Hallett, and J. A. Newman, "Will climate change be beneficial or detrimental to the invasive swede midge in North America? Contrasting predictions using climate projections from different general circulation models," Global Change Biology, vol. 14, no. 8, pp. 1721-1733, 2008.

[14] R. W. Sutherst, G. F. Maywald, and D. J. Kriticos, CLIMEX Version 3 User's Guide, Hearne Scientific Software Pty Ltd., 2007.

[15] O. Olfert, R. M. Weiss, S. Woods, H. Philip, and L. Dosdall, "Potential distribution and relative abundance of an invasive cereal crop pest, Oulema melanopus (coleoptera: chrysomelidae), in Canada," Canadian Entomologist, vol. 136, no. 2, pp. 277-287, 2004.

[16] R. W. Sutherst and G. Maywald, "A climate model of the red imported fire ant, Solenopsis invicta Buren (hymenoptera: formicidae): implications for invasion of new regions, particularly Oceania," Environmental Entomology, vol. 34, no. 2, pp. 317-335, 2005.

[17] D. W. McKenney, A. A. Hopkin, K. L. Campbell, B. G. Mackey, and R. Foottit, "Opportunities for improved risk assessments of exotic species in Canada using bioclimatic modeling," Environmental Monitoring and Assessment, vol. 88, no. 1-3, pp. 445-461, 2003. 
[18] O. Olfert, R. Hallett, R. M. Weiss, J. Soroka, and S. Goodfellow, "Potential distribution and relative abundance of swede midge, Contarinia nasturtii, an invasive pest in Canada," Entomologia Experimentalis et Applicata, vol. 120, no. 3, pp. 221-228, 2006.

[19] P. G. Mason, O. Olfert, L. Sluchinski et al., "Actual and potential distribution of an invasive canola pest, Meligethes viridescens (coleoptera: nitidulidae), in Canada," Canadian Entomologist, vol. 135, no. 3, pp. 405-413, 2003.

[20] B. S. Nielsen and T. S. Jensen, "Spring dispersal of Sitona lineatus: the use of aggregation pheromone traps for monitoring," Entomologia Experimentalis et Applicata, vol. 66, no. 1, pp. 2130, 1993.

[21] J. R. Fisher, The population dynamics of the pea leaf weevil Sitona lineatus (L.) in northern Idaho and eastern Washington, Ph.D. Dissertation, University of Idaho, Moscow, Idaho, USA, 1977.

[22] H. W. Prescott and M. M. Reeher, The Pea Leaf Weevil: An Introduced Pest of Legumes in the Pacific Northwest, United States Department of Agriculture, Harrisburg, Pa, USA, 1961.

[23] V. H. Hans, "Beitrage zur biologie von Sitona lineatus L.," Zeitschrift für angewandte Entomologie, vol. 44, pp. 343-386, 1959.

[24] D. J. Jackson, "Bionomics of weevils of the genus Sitones injurious to leguminous crops in Britain," Annals of Applied Biology, vol. 7, no. 3, pp. 269-298, 1920.

[25] D. J. Schotzko and S. S. Quisenberry, "Pea leaf weevil (coleoptera: curculionidae) spatial distribution in peas," Environmental Entomology, vol. 28, no. 3, pp. 477-484, 1999.

[26] J. Lerin, "Modeling embryonic development in Sitona lineatus (coleoptera: curculionidae) in fluctuating temperatures," Environmental Entomology, vol. 33, no. 2, pp. 107-112, 2004.

[27] O. Olfert, S. Meers, H. A. Cárcamo, and S. Hartley, "Pea leaf weevil in Alberta and Saskatchewan in 2009," in 2009 Crop Variety Highlights and Insect Pest Forecasts. Technical Bulletin No. 2010-01, pp. 18-19, Saskatoon Research Centre, Saskatoon, Canada, 2010.

[28] M. New, M. Hulme, and P. Jones, "Representing twentiethcentury space-time climate variability. Part I: development of a 1961-1990 mean monthly terrestrial climatology," Journal of Climate, vol. 12, no. 2-3, pp. 829-856, 1999.

[29] G. L. Baskerville and P. Emin, "Rapid estimation of heat accumulation from maximum and minimum temperatures," Ecology, vol. 50, no. 4, pp. 514-517, 1969.

[30] IPCC, Climate Change 2007: The Physical Science Basis, Contribution of Working Group I to the Fourth Assessment Report of the Intergovernmental Panel on Climate Change, Cambridge University Press, Cambridge, UK, 2007.

[31] P. H. Whetton, K. L. McInnes, and R. N. Jones, Australian Climate Change Projections for Impact Assessment and Policy Application: A Review, CSIRO Marine and Atmospheric Research, Melbourne, Australia, 2005.

[32] D. J. Kritcos, N. S. Alexander, and S. M. Kolomeitz, "Predicting the potential geographic distribution of weeds in 2080," in Proceedings of the 15th Australian Weeds Conference, Weed Science Society of South Australia, Adelaide, Australia, 2006.

[33] ESRI Inc., ArcView, Version 8.1, Redlands, California: Environmental Systems Research Institute Incorporated, 2001.

[34] M. Markkula and S. Roivainen, "The effect of temperature, food plants, and starvation on the oviposition of some Sitona (Col., curculionidae) species," Annales Entomologici Fennici, vol. 27, pp. 30-45, 1961.

[35] Pulse Canada, http://www.pulsecanada.com/statistics.
[36] Agriculture and Agri-Food Canada, Drought Watch, Prairie Farm Rehabilitation Administration, http://www.agr.gc.ca/ pfra/drought/maps/archives/e2030831.pdf.

[37] O. Olfert, S. Meers, H. A. Cárcamo, and S. Hartley, "Pea leaf weevil in Alberta and Saskatchewan in 2008," in 2008 Crop Variety Highlights and Insect Pest Forecasts. Technical Bulletin No. 2009-01, Saskatoon Research Centre, Saskatoon, Canada, 2009.

[38] O. Olfert, S. Meers, H. A. Cárcamo, and S. Hartley, "Pea leaf weevil in Alberta and Saskatchewan in 2007," in 2007 Crop Variety Highlights and Insect Pest Forecasts. Technical Bulletin No. 2008-01, pp. 18-19, Saskatoon Research Centre, Saskatoon, Canada, 2008.

[39] O. Olfert, R. M. Weiss, and D. Kriticos, "Application of general circulation models to assess the potential impact of climate change on potential distribution and relative abundance of Melanoplus sanguinipes (fabricius) (orthoptera: acrididae) in North America," Psyche, vol. 2011, Article ID 980372, 9 pages, 2011.

[40] O. Olfert and R. M. Weiss, "Impact of climate change on potential distributions and relative abundances of Oulema melanopus, Meligethes viridescens and Ceutorhynchus obstrictus in Canada," Agriculture, Ecosystems and Environment, vol. 113, no. 1-4, pp. 295-301, 2006.

[41] J. M. Jeschke and D. L. Strayer, "Usefulness of bioclimatic models for studying climate change and invasive species," Annals of the New York Academy of Sciences, vol. 1134, pp. 124, 2008.

[42] R. G. Pearson and T. P. Dawson, "Predicting the impacts of climate change on the distribution of species: are bioclimate envelope models useful?" Global Ecology and Biogeography, vol. 12, no. 5, pp. 361-371, 2003.

[43] Western Committee on Crop Pests, http://www.westernforum.org/IPMNMain.html. 

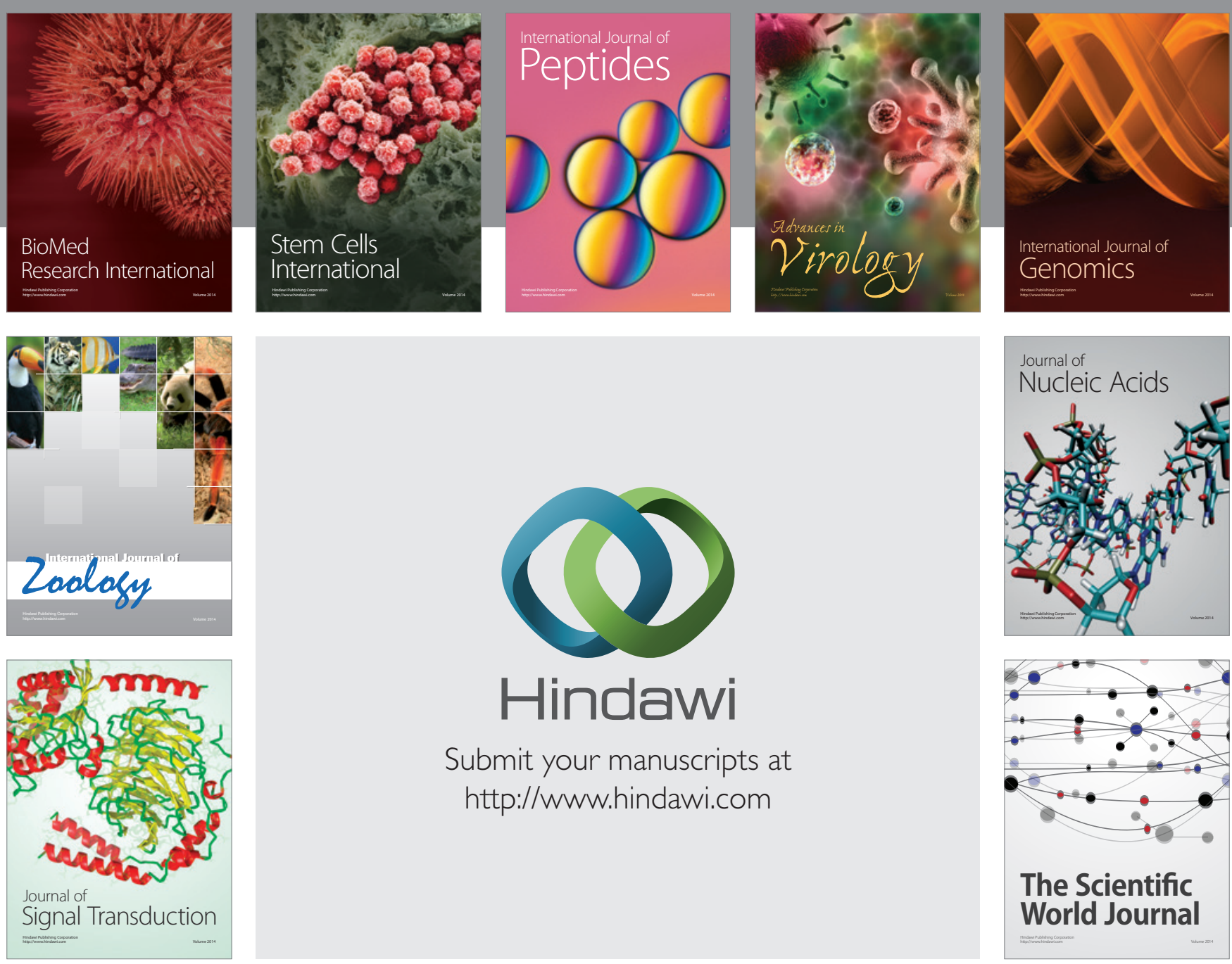

Submit your manuscripts at

http://www.hindawi.com
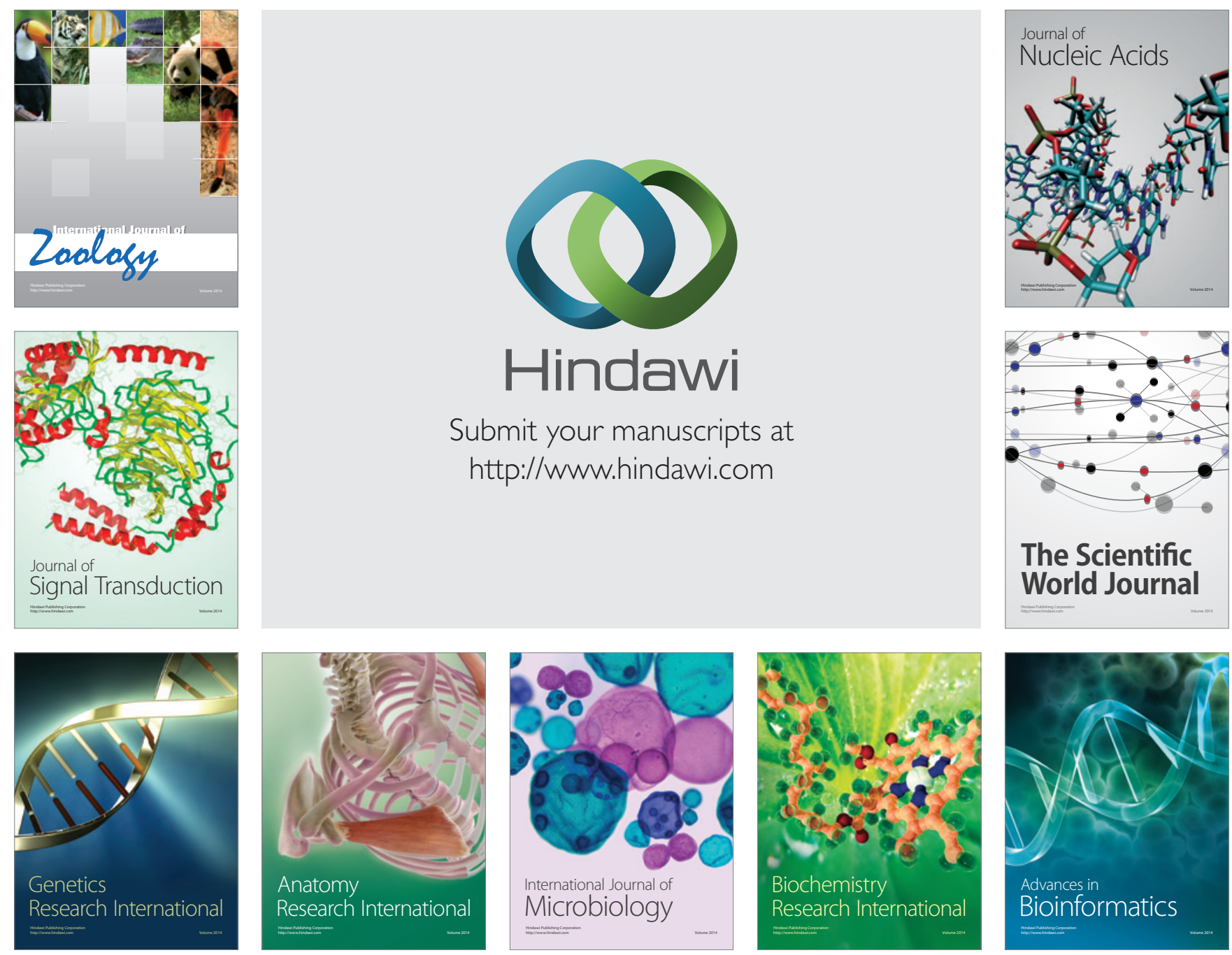

The Scientific World Journal
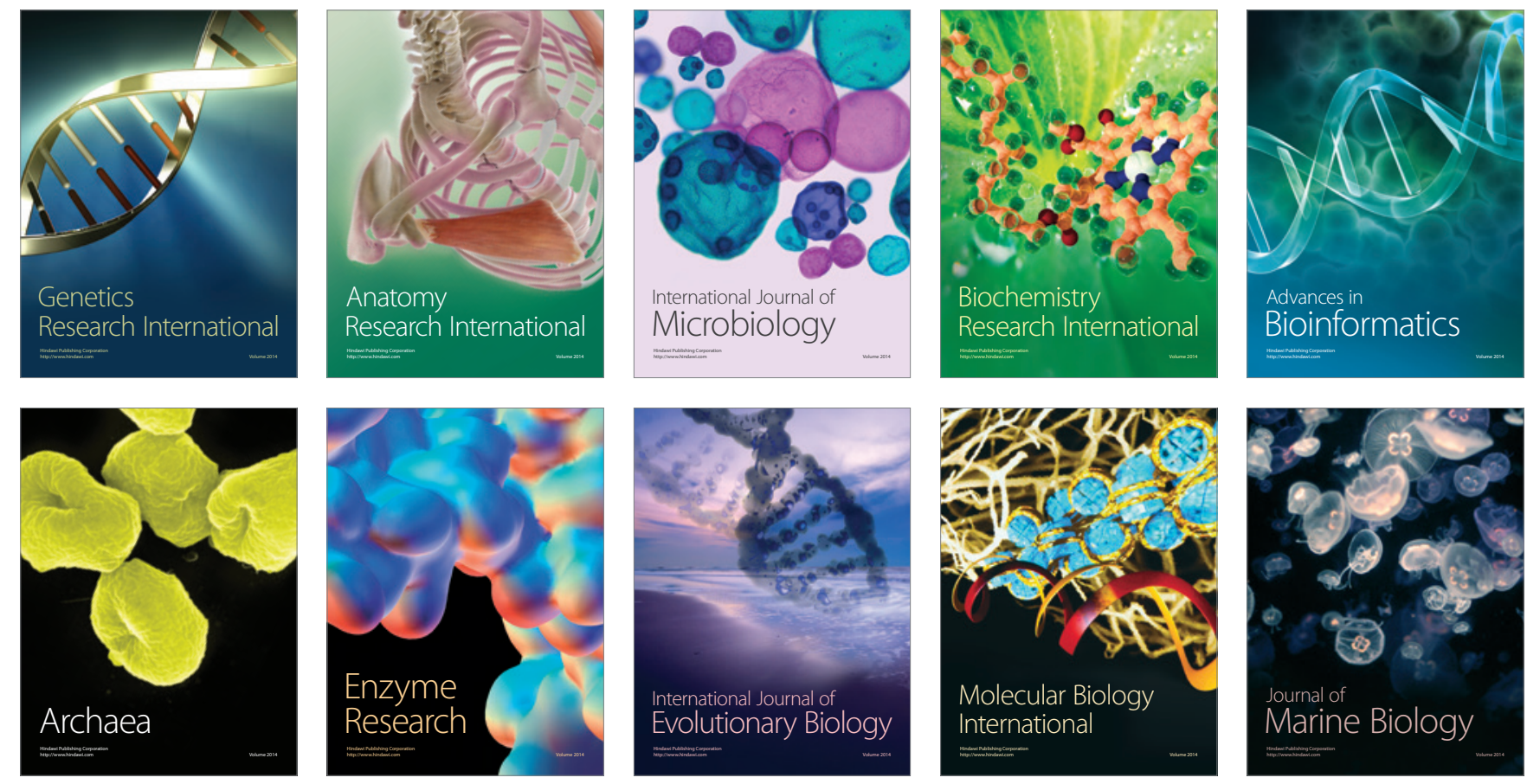